\title{
Metal Speciation in Sediment from Muara Angke, Jakarta Bay Using of BCR Sequential Extraction Procedure
}

\author{
Lestari* and Fitri Budiyanto \\ Research Centre for Oceanography, Indonesia Institute of Science \\ Jl. Pasir Putih I Ancol Timur Jakarta Utara 14430, Indonesia \\ Email: lest001@lipi.go.id
}

\begin{abstract}
The assessment of the biological availability of metals is rarely used only by knowing the total concentration of the metal. Therefore, six sediment samples from Muara Angke, Teluk Jakarta were assessed the chemical speciation of heavy metals. This study aims to determine metal speciation using the BCR sequential extraction procedure and to determine metal speciation to evaluate bioavailability in the sediments of Muara Angke, Jakarta Bay. In sediment from Muara Angke, the ability to move sequence of heavy metals studied was $\mathrm{Pb}>\mathrm{Zn}>\mathrm{Cu}>\mathrm{Ni}$. The mostly accumulated in the non-residual fraction of the total concentrations are $\mathrm{Cu}, \mathrm{Ni}, \mathrm{Pb}$ and $\mathrm{Zn}$ which indicated that the mobility and anthropogenic inputs of these metals in Muara Angke were quite high. The Risk Assessment Code $(R A C)$ reveal that $\mathrm{Zn}$ and $\mathrm{Ni}$ at almost station exist in exchangeable and a fraction of carbonate-bound and therefore high-risk category. Most of the $\mathrm{Cu}$ at most of the station is in the oxidizable fraction, except a small portion found at all station is in the exchangeable fraction and fraction of carbonate-bound thus posing a low risk for the waters environment. The patterns of $P b$ speciation show no to low risk to the waters environment. However, metal observations in the waters are necessary because they are persistent and can accumulate which threatening the water environment.
\end{abstract}

Keywords: metal speciation, sediments, Muara Angke, Jakarta Bay

\section{Introduction}

Metals are an appearing and persistent contamination problem faced by the human (Luoma and Rainbow, 2008). As a place to store the main and the metal source in the aquatic environment, sediment participates in the role of transporting and storing heavy metals that have potential hazards (Castillo et al., 2013). Notably, studies about total metal concentration in sediment cannot adequate to reflect about mobility, bioavailability, and toxicity. (Campbell et al., 1988). Their attributes do not only rely on their total metal content but also on the physicochemical form they happen (Davidson et al., 1994). Ure et al. (1993) has been described it as speciation. The metals such chromium $(\mathrm{Cr})$, copper $(\mathrm{Cu})$, lead $(\mathrm{Pb})$, zinc $(\mathrm{Zn})$, and mercury $(\mathrm{Hg})$ can become toxic and bioaccumulate in biological tissues and can biomagnify through the food chain (Luoma and Rainbow 2008, García-Alonso et al., 2016). The bioavailability and toxicity of metals depend upon their partition and chemical speciation (Luoma and Rainbow 2008, García-Alonso et al., 2016).

Sequential extraction procedure is evolved to analyze a different fraction of metals/metals bound in sediment. Sequential extraction procedure used selective chemical reagents to obtain a continuing dissolution of variant mineralogical phases and the next release of metals. The European Union's BCR (The Community Bureau of Reference - BCR, presently as the Standards, Measurements and Testing programme - SM\&T) developed a sequential extraction procedure. They are offered to get three fractions named an acid-soluble, a reducible and an oxidizable fraction (Ure et al., 1993; Quevauviller et al., 1997; Rauret et al., 1999; Cuong and Obard 2006; Santos et al., 2011; Teuchies et al., 2013; Islam et al., 2015). A scheme of a BCR sequential extraction procedures requires the several metals extraction in sequence to enlarge of metal reactivity. Metals speciation in sediments applied these procedures to produce three separate fractions (an acid soluble-extractable; a reducible; and an oxidable) (Qiao et al., 2013).

Jakarta Bay has been ecologically degenerated because of input biological and chemical pollutants from the sea and mainland areas (Williams et al., 2000; Arifin, 2004; Lestari et al., 2018). These pollutants were release from highland regions then were carried away through 13 rivers run into Jakarta Bay, including Angke River (Cordova and Riani, 2011). It disrupts water quality in Angke River and creates mass death of fish in 
mid-December 2015. Previous studies of total metals (Hutagalung, 1994; Williams et al., 2000; Rochyatun and Rozak, 2007) and metal speciation (Takarina et al., 2008 and Lestari et al., 2018) has been carried out. The total metal concentration is infrequently beneficial in defining its biological availability because metals in an environment of sediment happen in both dissolved and particulate condition and a type of chemical forms (Campbell et al., 1988). The purposes of this research are to determine metal speciation using the BCR sequential extraction procedure and to assess the bioavailability of metal in the sediments of Muara Angke, Jakarta Bay.

\section{Materials and Methods}

Six samples of sediment were taken from the sediment surface layer from that sites in that period, using stainless steel ponar grab was then subsample using polyethylene spoon and immediately put into an acid pre-cleaned polyethylene sample container (Loring and Rantala, 1992) (Figure 1).

The speciation method of BCR three-step sequential extraction procedure provides information on four fractions: i.e., exchangeable and carbonates; reducible; oxidizable; and residual (Table 1.). This method was modified by Cuong and Obard (2006) is followed by a little modification in step 4. The metal content of the residue from step 3 and the total metal content determined using microwave-assisted acid digestion procedure. Dry sediment samples were weighed as much as $1 \mathrm{~g}$ then digested with $10 \mathrm{ml}$ of $\mathrm{HNO}$ : $\mathrm{HCl}(1: 3)$ acid mixture in a microwave MarsExpress. Before analyzed by flame atomic absorption (FAAS) using Varian SpectraA 20, the supernatant has to be clear by centrifugation procedure (3000 rpm for $10 \mathrm{~min}$ ).

The US NOAA's sediment quality guidelines were used to compare with these total metals to estimate the probable environmental impact (Ramirez et al., 2005). Using the effects range low (ERL) and effects range median (ERM) for representing minimum level and maximum tolerable level of metals. In general, contrary results happen smaller than $10 \%$ of research in which the concentrations were below the respective ERL values, and were observed in greater than $75 \%$ of research in which the concentrations exceeded ERM values (Long et al., 1995).

The speciation study result showed that metals in the sediments are bound to different fractions with unique strength. An Indication of sediment reactivity to support the risk assessment of the presence of metals in Muara Angke given by these strength value. Evaluating sediment quality used The Risk Assessment Code criteria (RAC) (Jain, 2004; Turki, 2007; Horváth et al., 2013; Morelli and Gasparon, 2014). The Risk Assessment Code (RAC) criteria showed that sediment is removing an exchangeable and a carbonate fraction, smaller than $1 \%$ of the total metal, was reflected in secure for the environment. Otherwise, the sediment removing more significant than $50 \%$ of the total metal in the similar fraction has been thought about considerably hazardous and great probably enter the food chain.

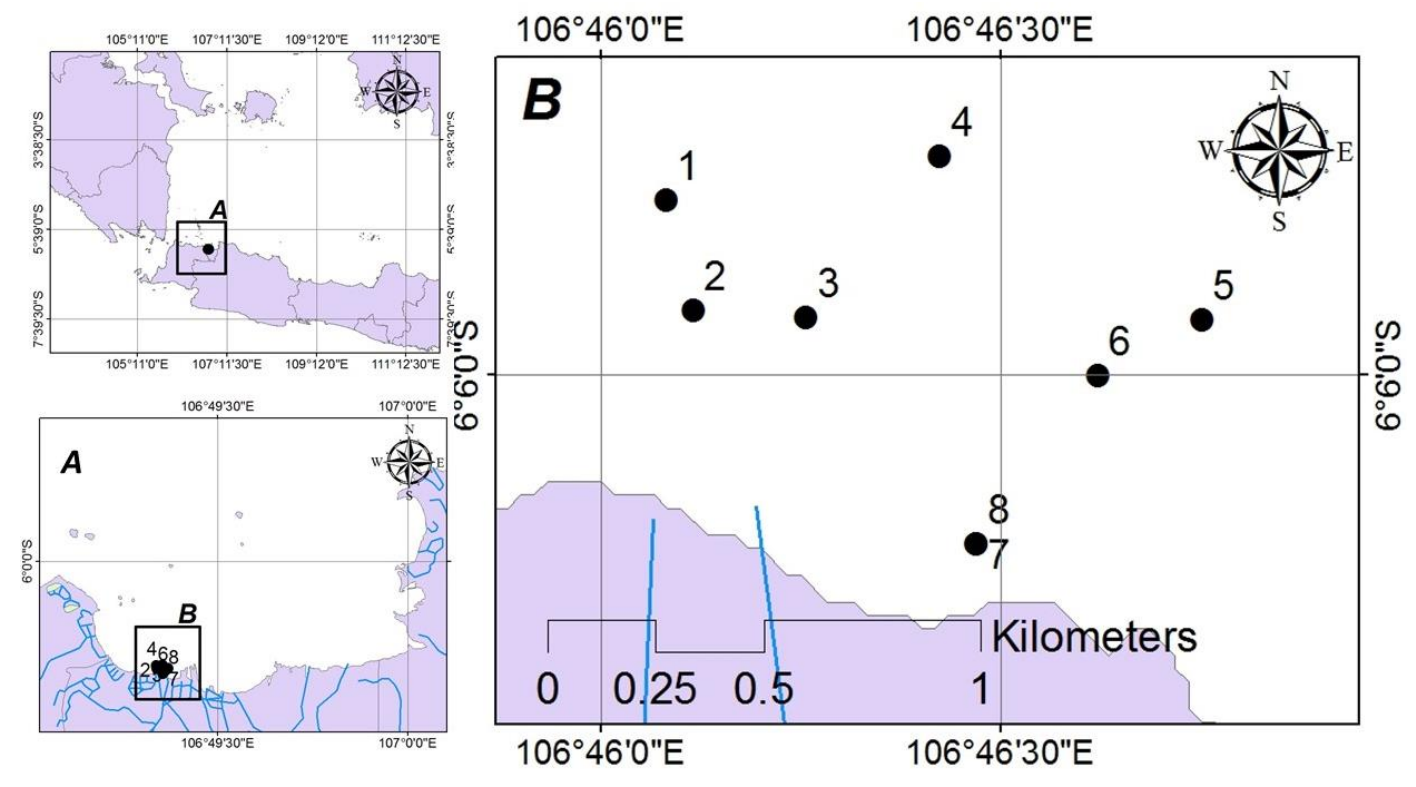

Figure 1. Sampling Location of the study area in Muara Angke, Jakarta Bay 
ILMU KELAUTAN: Indonesian Journal of Marine Sciences March 2019 Vol 24(1):23-30

Table 1. The main extraction steps for the BCR Sequential method (Ure et al., 1993 modified by Cuong and Obbard 2006)

\begin{tabular}{|c|c|c|c|c|}
\hline Step & Sediment phase & Reagent for extraction & Shaking time and temperature & Volume \\
\hline F1 & $\begin{array}{l}\text { acid-soluble fraction - } \\
\text { bound to carbonates }\end{array}$ & $\begin{array}{l}40 \mathrm{ml} \text { of } 0.11 \mathrm{~mol}^{-\mathrm{L}^{-1}} \\
\mathrm{CH}_{3} \mathrm{COOH}\end{array}$ & $\begin{array}{l}16 \mathrm{~h} \text { at room temperature at } 22 \pm 5^{\circ} \mathrm{C} \text { and } \\
\text { speed } 30 \pm 10 \mathrm{rpm} \text {. } \\
\text { The extract was separated from the solid } \\
\text { phase by centrifugation at } 3000 \mathrm{rpm} \text { for } 20 \\
\text { min. }\end{array}$ & $40 \mathrm{ml}$ \\
\hline $\mathrm{F} 2$ & $\begin{array}{l}\text { reducible fraction - bound } \\
\text { to Fe and Mn oxides) }\end{array}$ & $\begin{array}{l}40 \mathrm{ml} \text { of } 0.5 \mathrm{~mol} . \mathrm{L}^{-1} \\
\mathrm{HONH}_{2} \cdot \mathrm{HCl}(\mathrm{pH} \mathrm{1.5})\end{array}$ & $\begin{array}{l}16 \mathrm{~h} \text { at room temperature } 22 \pm 5^{\circ} \mathrm{C} \text { and speed } \\
30 \pm 10 \mathrm{rpm} \text {. } \\
\text { The extract was separated from the solid } \\
\text { phase by centrifugation at } 3000 \mathrm{rpm} \text { for } 20 \\
\text { min. }\end{array}$ & $40 \mathrm{ml}$ \\
\hline F3 & $\begin{array}{l}\text { Oxidizable fraction- bound } \\
\text { to organic matter and } \\
\text { sulfides }\end{array}$ & $\begin{array}{l}10 \mathrm{ml} \text { of } 8.8 \text { mol.L-1 } \\
\mathrm{H}_{2} \mathrm{O}_{2} \text { (two times), cool } \\
\text { and add } 50 \mathrm{~mL} \text { of } 1 \\
\text { mol. } \mathrm{L}^{-1} \mathrm{NH}_{4} \mathrm{OAc}(\mathrm{pH} 2)\end{array}$ & $\begin{array}{l}1 \mathrm{~h} \text { at room temperature } \\
1 \mathrm{~h} \text { at } 85^{\circ} \mathrm{C} \\
1 \mathrm{~h} \text { at } 85^{\circ} \mathrm{C} \\
16 \mathrm{~h} \text { at room temperature } 22 \pm 5^{\circ} \mathrm{C} \text { and speed } \\
30 \pm 10 \mathrm{rpm} \text {. } \\
\text { The extract was separated from the solid } \\
\text { phase by centrifugation at } 3000 \mathrm{rpm} \text { for } 20 \\
\text { min. }\end{array}$ & $50 \mathrm{ml}$ \\
\hline $\mathrm{R}$ & $\begin{array}{l}\text { Residual fraction - } \\
\text { strongly associated to the } \\
\text { crystalline structures of } \\
\text { minerals }\end{array}$ & $\begin{array}{l}10 \mathrm{~mL} \text { of aqua regia (3 } \\
\mathrm{HCl}: 1 \mathrm{HNO} \text { ) }\end{array}$ & Digesting in a mixture aqua regia & $50 \mathrm{ml}$ \\
\hline
\end{tabular}

\section{Results and Discussions}

The determination of heavy metals used testing the accuracy and precision for the extraction procedure. The sums of the metals concentrations get from the sequential extraction of $1.00 \mathrm{~g}$ of Certified References Material (CRM). Their total metal contents compared with PACS-2 (Cuong and Obbard, 2006). Table 2 summarized from the value that found to be acceptable (87-98\%) of the get recovery. A marine sediment standard reference material (PACS-2, National Research Council, Canada) was also to use for the accuracy of the microwave assisted acid digestion procedure for total metal determinations. The result showed satisfactory accuracy from this analysis, for the recoveries of all metals in PACS 2 between 91-96 \%.

The concentrations of total metal in surface sediments of Muara Angke are shown in Figure 2. Concentrations of $\mathrm{Cu}, \mathrm{Ni}, \mathrm{Pb}$ and $\mathrm{Zn}$ varied 29.075.9 mg. kg-1 dry weight (dw); 16.3-21.6 mg. kg-1 dw; 11.7-36.3 mg. kg-1 dw; and 83.4-360 mg.kg-1 dw, respectively. Compared with the previous study in this area, such as site JK 06 (Williams et al., 2000) are lower than this study. The mean concentration of metals in Muara Angke reduce in the sequence $\mathrm{Zn}>\mathrm{Cu}>\mathrm{Pb}>\mathrm{Ni}$. Sediment type in these area study showed the predominance of mud in station 1,2,4 and 7 meanwhile in station 5, and 6 contains sands. The concentration of organic matter (loss in ignition) are varying from $7.5-15.7 \%$.
The $\mathrm{Cu}$ and $\mathrm{Zn}$ concentrations were above the ERL values although they were still below the ERM values. However, most of the $\mathrm{Pb}$ and $\mathrm{Ni}$ concentrations were below both the ERL and ERM values. The total $\mathrm{Cu}$ and $\mathrm{Zn}$ contents in sediments were above moderately polluted or polluted levels. Table 3 presented the metals concentration in the studied area as well as the ERL and ERM value. Table 4 showed the non-residual and residual portioning of Copper ( $\mathrm{Cu})$, Nickel $(\mathrm{Ni})$, Lead $(\mathrm{Pb})$ and Zinc $(\mathrm{Zn})$ in the marine sediments. Associated their total content and speciation give the potential environmental risk of metals in sediments.

Figure 3 describes the partitioning of heavy metals varied considerably in every station. The Cuorganic complexes formation contributed to the existence of Copper inorganic fraction (39.6\%). Copper (29.3\%) was bound to Fe-Mn oxides. Copper in the exchangeable fraction was $5.08 \%$ and in residual fraction was $25.3 \%$. Copper bound in the residual fraction was dominated in other regions such as such as Banten Bay and Cirebon Waters (Lestari et al., 2018), Benoa Bay (Budiyanto et al., 2018). Metals relatively stable and inert, and they are hardly to release into the mobile and bioavailable phases when they bounded with the residual phase. This fraction contains crystallinebound trace metals and is dissolved with strong acids and specials digestion procedures (Hlavay et al., 2005; Turki, 2007). 
Table 2. Comparative result of analysis of the BCR sequential extraction procedure and total digestion on the certified reference material PACS-2 $(n=3)$.

\begin{tabular}{lllll}
\hline & Copper(Cu) & Nickel $(\mathrm{Ni})$ & Lead $(\mathrm{Pb})$ & Zinc(Zn) \\
\hline $\begin{array}{l}\text { Sum of the three extraction step and } \\
\text { residual step }\end{array}$ & $278 \pm 11$ & $33.0 \pm 5.6$ & $157 \pm 1$ & $315 \pm 1$ \\
Total Metal & $279 \pm 6.6$ & $36 \pm 1.8$ & $179 \pm 1.5$ & $348 \pm 17$ \\
Recovery \% & 98 & 87 & 87 & 89 \\
Certified PACS 2 & $310 \pm 12$ & $39.5 \pm 233$ & $183 \pm 8$ & $364 \pm 23$ \\
Recovery \% Total metal & 91 & 90 & 98 & 96 \\
\hline
\end{tabular}

Table 3. US NOAA's ERL and ERM concentrations for the studied metals (values are in $\mathrm{mg}^{\mathrm{kg}} \mathrm{kg}^{-1} \mathrm{dry}$ weight)

\begin{tabular}{llllll}
\hline \multirow{2}{*}{ Station } & \multicolumn{3}{l}{ Element, in mg.kg-1 dry } & \\
\cline { 2 - 5 } & Copper(Cu) & Nickel (Ni) & Lead (Pb) & Zinc $(\mathrm{Zn})$ \\
\hline 1 & 74,5 & 19,5 & 36,3 & 360 \\
2 & 75,9 & 21,6 & 32,3 & 351 \\
4 & 52,2 & 20,1 & 24,6 & 225 \\
5 & 29,0 & 17,1 & 11,7 & 83,4 \\
6 & 37,7 & 16,3 & 17,1 & 105 \\
7 & & 67,1 & 18,6 & 25,0 & 200 \\
Elemental & background concentration & 55.0 & 75.0 & 12.5 & 70.0 \\
ERL & & 34,0 & 20,9 & 46,7 & 150 \\
ERM & & 270 & 51,6 & 218 & 410 \\
& non polluted & $<25$ & $<20$ & $<40$ & $<90$ \\
SQG & moderately polluted & $25-50$ & $20-50$ & $40-60$ & $90-200$ \\
& heavily polluted & $>50$ & $>50$ & $>60$ & $>200$ \\
\hline
\end{tabular}

Table 4. The average non-residual and residual proportion of elements (\%) in the sediments from Muara Angke

\begin{tabular}{|c|c|c|}
\hline Element & Non-Residual a & Residual b \\
\hline $\mathrm{Cu}$ & 74.7 & 25.3 \\
\hline $\mathrm{Ni}$ & 56.6 & 43.4 \\
\hline $\mathrm{Pb}$ & 94.8 & 5.2 \\
\hline $\mathrm{Zn}$ & 82.0 & 18.0 \\
\hline
\end{tabular}

$\mathrm{a}=$ non residual fraction, F1(acid soluble fraction) + F2 (reducible fraction) + F3 (organic fraction)

$\mathrm{b}=$. residual fraction

Nickel bounded in the residual fraction was the most substantial fraction (43.4\%) of total $\mathrm{Ni}$. The other fraction (17.6\%) have content Nickel in a reducible fraction. Nickel was partitioned $13.9 \%$ in the oxidizable fraction (F3) and $25.2 \%$ in the exchangeable and bound to carbonates fraction. Lead $(\mathrm{Pb})$ was partitioned among the reducible (F1=84.3\%), oxidizable ( $F 3=9.75 \%)$, and residual fractions ( $F 4=5.22 \%)$. The Lead percentage in exchangeable and bound to carbonates fraction was lower the method detection limit. The most significant fraction for Zinc (42.3\%) was exchangeable and bound to carbonates fraction. The other significant fraction (31.6\%) have content $\mathrm{Zn}$ was a reducible fraction. Zinc is partitioned $8.0 \%$ in oxidizable fraction and $8.0 \%$ in residual fraction. Similar with area in Shantou Bay, China (Qiao et al., 2013), Zn happen in fractions of weakly- bounded with an average of $41.04 \%$ was the most high levels then followed by reducible fraction (21.63\%), show that in the bay significant scavengers of $\mathrm{Zn}$ was carbonate and Fe/Mn hydrous oxides. Mainly, the percentage of $\mathrm{Zn}$ in weakly-bound fractions reduce downstream from 49.76-14.05\%, occurred with an increase from $12.62-40.00 \%$ in the residual fraction. Metals-related with the exchangeable ions and carbonates were easily remobilized by environmental alteration conditions such as $\mathrm{pH}$, salinity and they are the most labile bonds. Metals in reducible fraction can be liberated in the environment with a $\mathrm{pH}$ decrease and alteration from oxic to anoxic conditions in sediment. Similarly, metals bound to organic matter are released under oxidizing conditions. These three fractions are the labile or exchangeable and hazardous phases for the environment. They may alter depending upon the surrounding physical and geochemical conditions (Turki, 2007).

Figure 4 described the metal distribution in percent bar graphs in the four fractions obtained in our analysis. The partitioning showed that the percentages of metals associated with the nonresidual fractions (consist of exchangeable also with carbonate+ reducible + oxidizable (Table 4). 


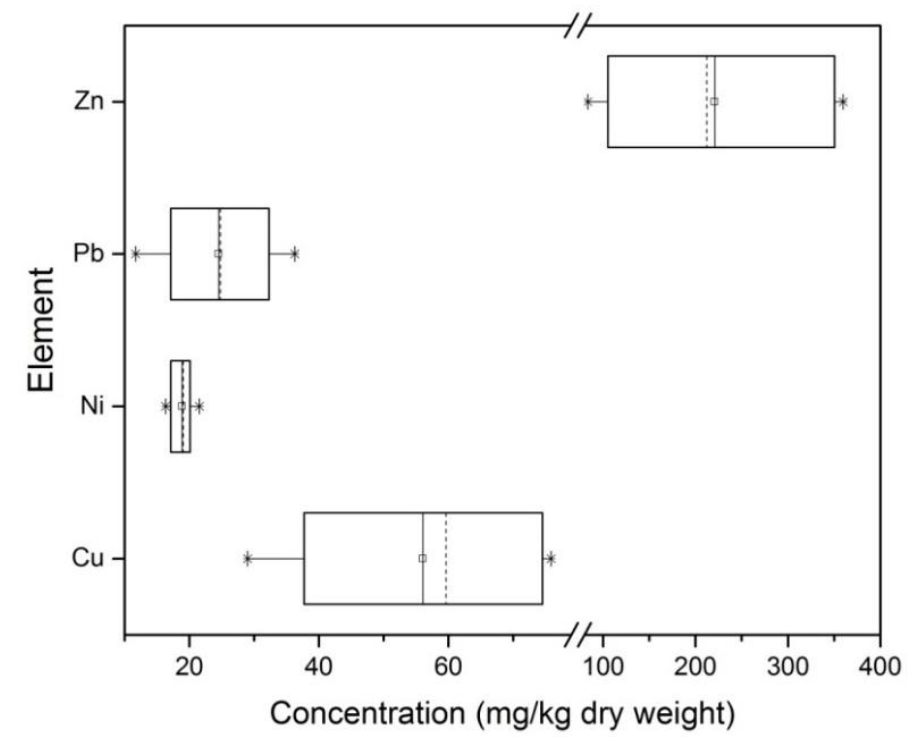

Figure 2. The box plot represented the total metal concentration in Muara angke: the mean (solid line); median (dash-line).
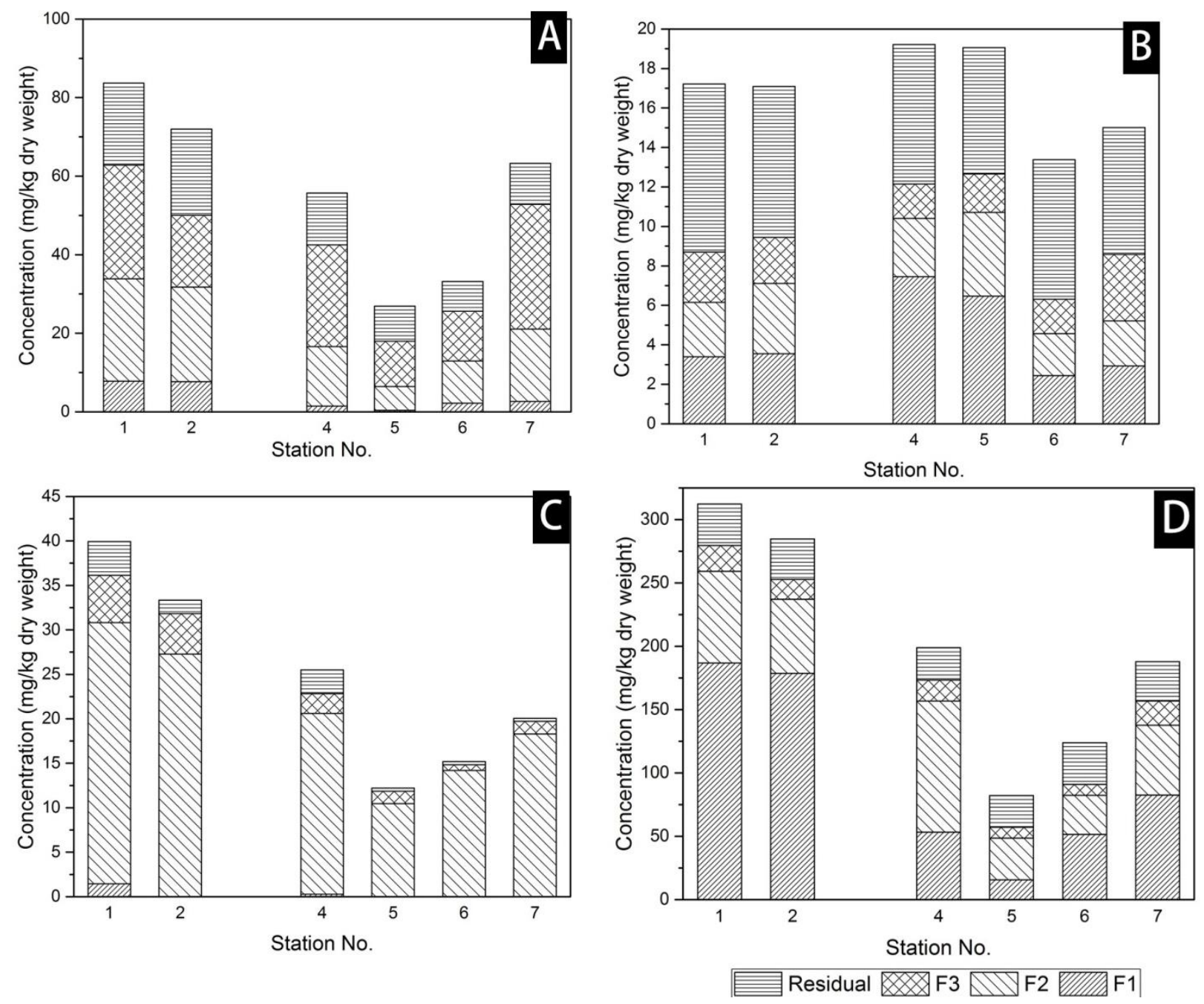

Figure 3. Chemical Partioning of heavy metal (mg.kg-1 dry weight) F1:acid soluble fraction, F2:reducible fraction, F3: organic fraction and residual in sediment sample at Muara Angke: $\mathrm{Cu}(\mathrm{A})$; $\mathrm{Ni}(\mathrm{B}), \mathrm{Pb}(\mathrm{C}) ; \mathrm{Zn}(\mathrm{D})$. 

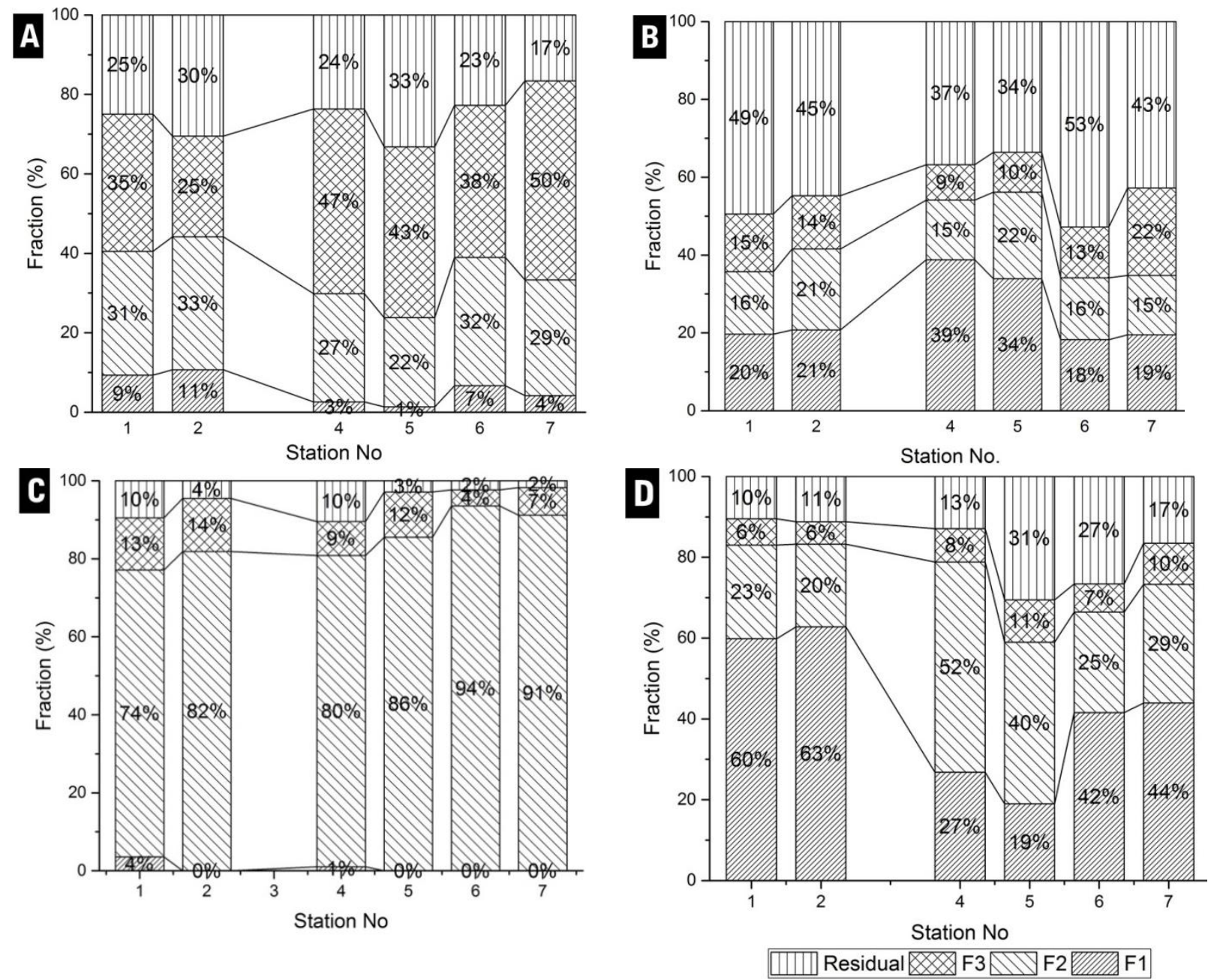

Figure 4. Removal percentage of (A) $\mathrm{Cu},(\mathrm{B}) \mathrm{Ni},(\mathrm{C}) \mathrm{Pb}$, and (D) $\mathrm{Zn}$ in each step of the sequential extraction procedure (F1:acid soluble fraction, F2:reducible fraction, F3: organic fraction and residual) applied for marine sediment at Muara Angke

Notably were higher (94.8\% for $\mathrm{Pb} ; 82 \%$ for $\mathrm{Zn} ; 74.7$ for $\mathrm{Cu}$ and $56.6 \%$ for $\mathrm{Zn}$ ) than those of the residual fraction $(5.2 \% \mathrm{~Pb} ; 18.8 \%$ for $\mathrm{Zn} ; 25.3 \% \mathrm{Cu}$ and 43.3\% for $\mathrm{Ni}$ ). These show that these metals were firstly obtained from an anthropogenic feed in even of the background of geochemical. The potentially of metals more available for exchange and release into the marine environment was indicated from our result. The non-residual fractions increased in the order of $\mathrm{Pb}<\mathrm{Zn}<\mathrm{Cu}<\mathrm{Ni}$ in this studied of metal.

Using of Risk Assessment Code (RAC) criteria to assess sediment quality as given below Table 5 . The code applied in our study revealed that about $41.6-62.8 \%$ of $\mathrm{Zn}$ at nearly all station was exchangeable and carbonate bound and enter the food chain. About 34-38.8\% of $\mathrm{Ni}$ at station Angke 4 is exchangeable and carbonate bound and beneath category of high-risk. Most of the copper at most of the stations are in the oxidizable fraction, except a small portion (1.37-10.7) found at all stations is in the exchangeable and carbonate bound fraction, so
Table 5. Risk Assessment Code (after Jain, 2004)

\begin{tabular}{cc}
\hline Risk Assessment Code (RAC) & Criteria (\%) \\
\hline No Risk & $<1$ \\
Low Risk & $1-10$ \\
Medium Risk & $11-30$ \\
High Risk & $31-50$ \\
Very High Risk & $>50$ \\
\hline
\end{tabular}

that gives a low risk for the environment of aquatic. Patterns of $\mathrm{Pb}$ speciation $(0-3.6 \%$ in exchangeable and carbonate bound) show no to low risk to the aquatic environment. However, metal observations in the waters are necessary because they are persistent and can accumulate which threatening the water environment.

\section{Conclusions}

Total Copper and Zinc contents in sediments were above moderately polluted or polluted levels based on SQG. Marine sediments in Muara Angke in 
consequence of anthropogenic impact were indicated in this study. Evaluation of the potential mobility and the possible transfer of heavy metals from sediments to the surrounding environment from Muara Angke, Jakarta Bay was applied using the BCR sequential extraction procedure. Copper, Nickel, Lead, and Zink were generally accumulated in a non-residual fraction which indicated that the mobility and anthropogenic inputs of these metals in Muara Angke were quite high. The mobility order of heavy metals studied was $\mathrm{Pb}>\mathrm{Zn}>\mathrm{Cu}>\mathrm{Ni}$ in sediment from Muara Angke. The Risk Assessment Code (RAC) reveal that Zink and Nickel at nearly all stations be in exchangeable and carbonate bound fraction and therefore high-risk category. Most of the copper at most of the stations are in the oxidizable fraction, except a small portion found at all stations is in the exchangeable and carbonate bound fraction, so that gives a low risk for the aquatic environment. Patterns of $\mathrm{Pb}$ speciation show no to low risk to the aquatic environment.

\section{References}

Arifin, Z. 2004. Local millennium Ecosystem Assessment: Condition and Trend of the Greater Jakarta Bay Ecosystem. The Ministry Environment, Republic of Indonesia

Budiyanto F., Lestari, Hindarti D., Rozak A., Kaisupy M,T., Purbonegoro T., Puspitasari R. \& Suratno. 2018. Speciation of copper and nickel in sediment from Benoa Bay, Bali by modified BCR procedure. AIP Conference Proceedings 2024: 020050; doi: 10.1063/1.5064336.

Campbell, P.G.C, Lewis, A.G., Chapman, P.M., Crowder, A.A., Fletcher, W.K., Imber, B., Luoma, S.N., Stokes, P.M. \& Winfrey, M. 1988. Biologically available metals in sediments, National Research council of Canada, Publication No. NRCC 27694

Castillo, M.L.A, Trujillo, I.S., Alonso, E.V., de Torres, A.G. \& Cano-Pavon, J.M. 2013. Biovaibility of heavy metal in water and sediment and sediments from a typical Mediterranean Bay (Malaga Bay, region of Andalucia, Southern Spain). Mar. Pol. Bull. 76: 427-434. doi: 10.1016/j.marpolbul.2013.08.031

Cordova, M.R. \& Riani, E. 2011. Konsentrasi logam berat $(\mathrm{Hg}, \mathrm{Cd}, \mathrm{Pb})$ pada air laut dan sedimen di muara sungai angke, Jakarta. J. Hidrosfir. 6(2):107-112

Cuong, D.T. \& Obbard, N. 2006. Metal speciation in coastal marine sediments from Singapore using a modified BCR-sequential extraction procedure. Applied Geochem. 21: 1335-1346. doi: 10.1016/j.apgeo chem.2006.05.001.

Davidson C.M., Thomas R.P., McVey S.E., Perala R., Littlejohn D. \& Ure A.M.1994. Evaluation of sequential extraction procedure for the speciation of heavy metals in sediments. Analytica Chimica Acta 291: 277-286. doi: 10.1016/0003-2670(94)8002 3-5

García-Alonso, J., Lercari, D., Araujo, B.F., Almeida, M.G. \& Rezende, C.E. 2017. Total and extractable elemental composition of the intertidal estuarine biofilm of the Río de la Plata: Disentangling natural and anthropogenic influences. Est. Coas. Shelf Sci. 187: 53-61. doi: 10.1016/j.ecss.2016.12.018.

Hlavay J., Prohaska T., Weisz M., Wenzel W.W. \& Stingeder J. 2004. Determination of trace elements bound to soils and sediment fractions (IUPAC Technical Report). Pure Appl. Chem., 76(2): 415-442

Horváth, M., Halász, G., Kucanová, E., Kuciková, B., Fekete, I., Remeteiová, D., Heltai, G. \& Flórián, K., 2013. Sequential extraction studies on aquatic sediment and biofilm samples for the assessment of heavy metal mobility. Microchem. J. 107: 121-125. doi: 10.1016/j. microc.2012.05.024

Hutagalung, H.P. 1994. Heavy metals in sediment of Jakarta Bay. In Proceedings of monitoring marine pollution. Hutagalung H.P. (ed) pp 1-6. Puslitbang Oseanologi-LIPI, Jakarta.

Islam, M.S., Ahmed, M.K. \& Al Mamun, M.H. 2015. Geochemical speciation and risk assessment of heavy metals in sediments of a river in Bangladesh. Soil and Sediment Contamination, 24: 639-655. doi: 10.1080/15320383.2015. 997869

Jain, C.K. 2004 Metal fractionation study on bed sediments of River Yamuna, India, Wat. Res., 38: 569-578

Lestari, F., Budiyanto \& Hindarti D. 2018. Speciation of heavy metals $\mathrm{Cu}, \mathrm{Ni}$ and $\mathrm{Zn}$ by modified BCR sequential extraction procedure in sediments from Banten Bay, Banten Province, Indonesia. Global Colloquium on GeoSciences and Engineering 2017, IOP Conf. Series: Earth and Environ. Sci. 118: 012059 doi: 10.1088/17 55-1315/ 118/1/012059. 
Lestari, Budiyanto F., Puspitasari R., Purbonegoro T., Cordova M. R. \& Hindarti $\quad$ D. 2018. Fractionation of metal in surface sediment from Cirebon coastal waters, West Java, Indonesia. AIP Conference Proc. 2024: 020062 doi: $10.1063 / 1.5064348$

Long, E.R., MacDonald, D.D., Smith, S.C. \& Calder, F.D. 1995. Incidence of adverse biological effects within ranges of chemical concentrations in marine and estuarine sediments. Environ. Man. 19(1): 81-97.

Loring, D.H. \& Rantala, R.T.T. 1992. Manual for the Geochemical Analyses of Marine Sediments and Suspended Particulate Matter. EarthScience Reviews, 32(4): 235-283. doi: 10.10 $16 / 0012-8252(92) 90001$

Luoma S.N. \& Rainbow P.S. 2008. Metal contamination in aquatic environments: science and lateral management. Cambridge University Press. 573 pp.

Morelli, G. \& Gasparon, M. 2014. Metal contamination of estuarine intertidal sediments of Moreton Bay, Australia. Mar. Pol. Bull. 89: 435-443. doi: 10.1016/j.marpolbul.2014.10. 002

Qiao, Y., Yang, Y., Gu, J. \& Zhao, J. 2013. Distribution and geochemical speciation of heavy metals in sediments from coastal area suffered rapid urbanization, a case study of Shantou Bay, China. Mar. Pol. Bull. 68: 140146. doi: 10.1016/j.marpolbul.2012.12.003.

Quevauviller, P., Rauret, G., López-Sánchez, J.F., Rubio, R., Ure, A. \& Muntau, H. 1997. Certification of trace metal extractable contents in a sediment reference material (CRM 601) following a three-step sequential extraction procedure. Sci. Total Environ. 205(2-3): 223234.

Ramirez, M., Massolo, S., Frache, R. \& Correa, J. A., 2005. Metal speciation and environmental impact on sandy beaches due to El Salvador copper mine, Chile. Mar. Poll. Bull. 50: 62-72. doi: 10.1016/j. marpolbul.2004.08.010

Rauret, G., Lopez-Sanchez, J.F., Sahuquillo, A., Rubio, R., Davidson, C., Ure, A. \& Quevauviller,
P. 1999. Improvement of the BCR three step sequential extraction procedure prior to the certification of new sediment and soil reference materials. J. Environ. Mon. 1(1): 57-61. doi: 10.1039/ A807854H

Rochyatun, E., \& Rozak, A. 2007. Pemantauan Kadar Logam Berat dalam Sedimen di Perairan Teluk Jakarta. Makara Sains, 11(1): 28-36. doi: $10.7454 / \mathrm{mss} . v 11 \mathrm{i} 1.228$

Santos, A.M, Leitao, A.A. \& Boaventura, R.A.R. 2011. Heavy metal pollution of sediments from coastal areas: Assessment of the environmental impact of polluted surface sediment from the Bay of Luanda, Angola. J. Environ. Sci. Eng., 5(10): 1317-1336

Takarina, N.D, Wardhana, W. \& Budiawan, 2008. Geochemical association of heavy metals in sediments and environmental pollution at Jakarta Bay. Proceeding of The international Seminar on Chemistry Jatinangor 30-31 Okt. pp 717- 720.

Teuchies J., Singh, G., Bervoets, L. \& Meire, P. 2013. Land use changes and metal mobility: Multi approach study on tidal marsh restoration in a contaminated estuary. Sci. Total Environ. 449: 174-183. doi: 10.1016/j.scitotenv.2013.01. 053

Turki, A.J. 2007. Metal Speciation (Cd, Cu, Pb and $\mathrm{Zn}$ ) in Sediments from Al Shabab Lagoon, Jeddah, Saudi Arabia. Mar. Sci. 18(1): 191-210

Ure, A.M., Quevauviller, P., Muntau, H. \& Griepink, B. 1993. Speciation of heavy metals in soils and sediments. An Account of the improvement and harmonization of extraction techniques undertaken under the auspices of the BCR of the commission of the European communities. Int. J. Environ. Anal. Chem., 51: 135-151.

Williams, T.M., Ress, J.G. \& Setiapermana, D., 2000. Metals and trace organic compounds in sediment and waters of Jakarta Bay and the Pulau seribu Complex Indonesia. Mar. Poll. Bull. 40: 277-285. doi: 10.1016/S0025326X(99)00 226-X 